\title{
IN REM CLAIMS TO WEALTH AND SURVIVING VALUE
}

\author{
Peter Jaffey $^{*}$
}

\section{Introduction}

This article is intended to expose certain important misconceptions in the law governing claims to recover wealth or property, as it is presently understood, and to propound an alternative analysis that has a stronger theoretical basis and makes the law clearer and more coherent. The argument has implications for the availability of in rem restitutionary claims, the nature of tracing, and the theory of unjust enrichment.

Ownership of property is an in rem right, meaning that it is good 'against the whole world', without any requirement for a pre-existing relationship between the parties. This means that any recipient of property through an invalid $\operatorname{transfer}^{1}$ will incur a liability to the owner (subject to any defence that the recipient may have.) ${ }^{2}$ It is sometimes helpful to distinguish between the primary right of the owner, which is a general right against any possible or hypothetical recipient of an invalid transfer, and the remedial right - i.e. the claim - that arises as a response to an invalid transfer to a particular recipient. ${ }^{3}$ One can distinguish between two possible remedial regimes arising from an invalid transfer. Under the first, ownership of the property is retained because the transfer was invalid. This means that the claimant can acquire a claim against an indirect recipient of the property who has received it from the direct recipient; and, because the claim binds all third parties, the claim will be unaffected by the defendant's insolvency. ${ }^{4}$ This is the position taken in equity. Alternatively, there could be a regime under which ownership of the property is lost through the transfer, even though it is invalid, and the claim is merely an in personam claim to value. If this is the case, the claim will diminish in insolvency along with other in personam claims, and there is no possibility of a claim against an indirect recipient of

\footnotetext{
* I am grateful to Patrick Polden, Lesley Turano, Steve Allen and Riz Mokal for their comments.

${ }^{1}$ The concept of invalidity is considered below.

${ }^{2}$ e.g. bona fide purchase or the equity's darling defence; as to change of position, see the section below on tracing.

${ }^{3}$ Lord Diplock made a much-cited reference to the distinction between the primary right to performance in contract and the remedial right or claim to compensation for breach of contract in Photo Productions Ltd v Securicor Transport Ltd [1980] AC 827. The terminology appears to come from European civil law: see B Dickson, 'The Contribution of Lord Diplock to the General Law of Contract' (1989) 9 Oxford Journal of Legal Studies 441.

${ }^{4}$ Subject to the 'apparent wealth' argument considered below, text following n.56.
} 
the property. This is generally the position taken by the common law. ${ }^{5}$ The latter regime is open to the objection that it gives some effect to the invalid transfer: the implication is that, although invalid as against the direct recipient, the transfer is effective so far as third parties are concerned. In principle it seems right that if the transfer is invalid as against the direct recipient it should also be invalid as against third parties, so that ownership is retained and the claim is in rem.

'Property', the subject matter of ownership, is generally taken to be a tangible thing, or at least a 'specific asset' in the sense discussed below. The main part of this article is concerned with the right to wealth, i.e. transferable or exchangeable value. Wealth may take the form of a tangible thing, but insofar as it is treated as wealth, its value is its exchange value, not any special value that it may have for the owner as a tangible thing. Most importantly, wealth takes the form of value held for exchange or investment by way of money as notes or coins, ${ }^{6}$ or in the form of 'pure value', held by way of a debt-right - i.e. in a bank account or in the form of some other investment. ('Debt-right' is used to signify the right of the creditor as opposed to the liability of the debtor in relation to the debt.)

It is often assumed that there cannot be ownership of, or an in rem right to, wealth, except where it consists of tangible things, and that a right to pure value must be in personam, for example a claim in debt. But, to the contrary, as is argued below, and as seems generally to be assumed in non-technical or informal contexts, wealth including pure value can be the subject matter of ownership in more or less the same way as tangible things, or, as one might express it, 'property' can encompass wealth as pure value as well as tangible things; and, furthermore, not only is there a primary in rem right to wealth, but also the claim arising from an invalid transfer of wealth can be and generally ought to be in rem.

To avoid confusion it may be helpful at this point to mention an issue that will be dealt with more fully later. This article is concerned with 'invalid transfers' of property or wealth. An invalid transfer is a transfer that is not effected by a valid exercise by the owner of his power of disposition. ${ }^{7}$ This will be the case because of some factor affecting the exercise of the power like mistake, duress, undue influence

\footnotetext{
${ }^{5}$ Although not always, especially with respect to goods.

${ }^{6}$ Here the tangible thing is valuable as a token of the wealth that it represents.

${ }^{7}$ The 'transfer' is a transfer of possession or control. With respect to pure value, control refers to the right as creditor to deal in respect of a contractual debt. In equity, the legal title will pass with possession or control. See below, text following n.83.
} 
etc.; but the most important such factor for present purposes is 'lack of authority', where the putative transfer is made without authority by someone other than the owner. ${ }^{8}$ It seems straightforward to refer to these factors as 'vitiating factors', and to say that an invalid transfer is a vitiated transfer, the vitiation being the cause of the invalidity. However, this is generally denied: ${ }^{9}$ it is said that the invalidity of a transfer means that ownership of the property is retained by the claimant, who therefore has a claim to reverse the transfer arising from his pre-existing ownership of the property; but also that a transfer can be valid, so that ownership passes, but nevertheless vitiated, so that there is a claim to reverse the transfer based not on the claimant's preexisting ownership but on the principle of unjust enrichment. The point will be discussed fully later. ${ }^{10}$ For the moment it will be assumed that an invalid transfer is equivalent to a vitiated transfer, and that this supposed distinction between two types of claim is misconceived. ${ }^{11}$

\section{The right to wealth}

Ownership of property is generally contrasted with a contractual right to be paid a sum of money, for example the balance on a bank account. Here the primary right is in personam, good against the debtor only, and the claim arising from default is also in personam. But this does not provide a complete account of the creditor's position in relation to what would colloquially be described as the money in the account.

Take the case where $\mathrm{C}$ has $£ \mathrm{X}$ in an account with Bank A. Say $\mathrm{C}$ instructs Bank A to transfer $£$ X to D's account at Bank B. C had a contractual right against Bank A, which was discharged, and now D has a contractual right against Bank B. One might ask what it is that was transferred, since the contractual right was not. The answer appears to be that C's money or wealth was transferred. Certainly the creditor $\mathrm{C}$ would understand his position in this way. The implication is that $\mathrm{C}$ has a right to his wealth distinct from the debt-right against the bank. One might argue that there is

\footnotetext{
8 'Owner' includes beneficial owner. This could be an agent acting outside his authority or a trustee acting outside his powers or a stranger simply taking property. There is no implication that the person making the transfer has any authority to contract for the claimant: see further P Jaffey, The Nature and Scope of Restitution (Oxford, 2000), 161. Lack of authority corresponds to what is now commonly but inaptly referred to as 'ignorance', following P Birks, An Introduction to the Law of Restitution (Oxford, rev ed, 1989), 140ff.

${ }^{9}$ See below, n. 80 .

${ }^{10}$ As discussed below, the same distinction is often expressed as the distinction between title-based and non-titled based claims or between restitutionary (or unjust enrichment) and proprietary claims.
} 
no need to invoke any such concept in order to explain what happens here, and that everything can be explained in terms of contract: there is a debt owed to $\mathrm{C}$, and by agreement between the parties the debt to $\mathrm{C}$ from Bank $\mathrm{A}$ is discharged and a new debt owed by Bank B to D created.

But consider the case where Bank A transfers the $£ X$ in C's account to B without authorization from $\mathrm{C}$. Would $\mathrm{C}$ acquire a claim against $\mathrm{B}$ for the return of the money transferred, on the ground that the transfer was unauthorized? If such a claim arises, $\mathrm{C}$ must have a right to his wealth, meaning the money in the account, which is a right in rem, because it binds a recipient of it (B) in the absence of any prior relation. One might object, first, that in reality there is no 'money in the account' - the balance on the account is just the measure of a debt owed, not the measure of an actual sum of money belonging to $\mathrm{C}$. Thus if Bank A purports to reduce the balance on C's account when it has no contractual authority to do so, it must follow that the balance on the account does not actually change (whatever the books might for the moment state), and correspondingly that there is no transfer from $\mathrm{C}$ to $\mathrm{B}$ and no question of a claim against B. The transfer to B is actually of Bank A's money, and Bank A may have a claim, ${ }^{12}$ but this does not affect C. But in fact there are cases where there has been a transfer from C's account without his authority that generates a claim for $\mathrm{C}$ against the recipient. For example, say Bank A relies on the ostensible authority of C's agent or trustee with respect to the account, so that it is entitled to reduce the balance on the account. The money transferred then comes from $\mathrm{C}$, because there is a reduction in the value of the debt owed to $\mathrm{C}$ (or his trustee), and not from Bank A, whose net wealth is unchanged. ${ }^{13}$ If there was no actual authority to make the transfer under the terms of the agency or trust, ${ }^{14} \mathrm{C}$ will acquire a claim against $B{ }^{15}$ The claim serves to reverse an invalid transfer of wealth, the vitiating factor being the lack of authority for the transfer. The claim must arise from C's right

\footnotetext{
${ }^{11}$ It is not necessary to consider invalidity not due to a vitiating factor e.g. illegality, or claims to reverse a transfer based on contract or tort.

${ }^{12}$ As in Barclays Bank v Simms [1980] QB 677.

13 The bank of course draws on its own assets to make the payment but at the same time reduces its liabilities by debiting the sum from C's account, so the money comes from $\mathrm{C}$ not the bank.

${ }^{14}$ In the trust case, 'authority' signifies power or authority to make a transfer under the terms of the trust, not authority conferred by the claimant beneficiary.

${ }^{15}$ This is commonplace in equity. In cases where the trustee is said to have transferred trust funds in breach of trust, this generally means he has directed the trust's bank to transfer funds from the trust account. There are also cases at common law: e.g. Agip Africa v Jackson [1991] Ch 547, Lipkin Gorman v Karpnale [1991] 2 AC 548, Banque Belge pour L'Etranger v Hambrouck [1921] 1 KB 321, Trustee of the Property of FC Jones and Sons v Jones [1996] 3 WLR 703.
} 
to the wealth in his account. This is a primary in rem right, which can bind any recipient, and is distinct from the in personam contractual right against the bank.

One might immediately object that if $\mathrm{C}$ has an in rem right to the money in his bank account he must have, not an in personam right against the bank, but an in rem right in respect of some part of the bank's assets, which is of course not the case. But there is no contradiction. The claimant has an in rem right to his wealth, but if his wealth is invested by way of debt, the subject matter of the in rem right is lost, or at least suspended. The relation between the claimant and the bank is governed by the contract of deposit, and the debt-right is purely in personam. But if money is withdrawn or transferred from the account, the claimant has an in rem right to it. In practice there is no harm in saying that the claimant has an in rem right to the wealth in the account although only an in personam right against the bank. The in rem right operates only in respect of value withdrawn or transferred.

Thus there is a primary in rem right to wealth, so that an invalid transfer of wealth generates a claim against any recipient of it. This might seem to be a simple and obvious proposition. But, to the contrary, as mentioned above it is often said or assumed that an in rem right is necessarily a right in respect of a tangible thing (or, more broadly, as explained below, an 'asset'), and conversely that a right to wealth or value must necessarily be an in personam right to payment, e.g. a debt-right. Consequently it is thought that an in rem right to wealth is inconsistent with the nature of an in rem right - a simple contradiction in terms. The reason is no doubt that the original form of in rem right was the right of ownership of tangible property.

It is accepted by extension (in equity) that an in rem right can subsist in respect of a debt-right as well as a tangible thing. 'Asset' is used to encompass both. ${ }^{16}$ The concept of an in rem right to a debt-right can be illustrated as follows. If $\mathrm{C}$ is the beneficiary under a trust, and the trustee holds the trust money in a bank account, the trustee has a contractual right against the bank, but this contractual right is understood to be 'trust property' held on behalf of C. C is understood to have an in rem right (in equity) to the debt-right. But although $\mathrm{C}$ can be said to have a right to the debt-right in the name of the trustee, in the sense that he can direct the trustee as to how to exercise it, this is surely an in personam right against only the trustee as the contracting party. C's in rem right under the trust is surely his right to the trust money, in the sense

\footnotetext{
${ }^{16}$ There are of course other types of intangible asset that are not considered, e.g. intellectual property.
} 
explained above, i.e. to the wealth held on trust, in whatever form it may from time to time be invested, as against any person who might receive it by unauthorized transfer. ${ }^{17}$ The idea of the equitable in rem right to the common law debt-right as an asset is a legal device to avoid the explicit recognition of ownership of wealth as such. As the discussion above shows, at common law $\mathrm{C}$ actually has the same right to his wealth in the case where there is no trust and $\mathrm{C}$ has the in personam right against the bank in his own name. But at common law, where $\mathrm{C}$ is the creditor himself, there might seem to be a contradiction in saying that he has an in personam right against the bank and also an in rem right to the debt-right.

\section{The in rem claim arising from an invalid transfer of wealth}

If there has been an invalid transfer of wealth from the claimant to the defendant, the claimant has a claim to the value of the transfer. The claim arises from the claimant's ownership of - i.e. his in rem primary right to - his wealth. Two possible regimes arising from an invalid transfer were distinguished above in relation to tangible property. On one approach, ownership is lost as a result of the transfer and the claim is in personam; and on the other approach ownership is retained and the claim is in rem. As mentioned above (with respect to tangible property), the usual understanding is that the claim is, or in principle should be, an in rem claim of continuing ownership of the tangible property. Which regime is appropriate in relation to an invalid transfer of wealth?

Where a claim to reverse an invalid transfer of wealth arises at common law, for example from a mistaken payment, it has always been an in personam claim, the claim for money had and received. ${ }^{18}$ It seems that the claim is understood to be necessarily in personam because it is a claim to value, like a claim for compensation in contract or tort. In equity the analogous claim is the 'equitable proprietary claim', ${ }^{19}$ which traditionally arises where there is a transfer by a trustee or fiduciary acting beyond his power. This claim is in rem; and this is thought to be possible only

\footnotetext{
${ }^{17}$ This is implicit in the concept of the trust fund, where the subject of ownership is really the value of the fluctuating body of assets making up the fund.

${ }^{18}$ Originally this was a claim arising from a transfer of money as coins, but it also applies to other forms of wealth including money in an account.

${ }^{19}$ The equitable proprietary claim is said to arise under a constructive trust or a resulting trust but to avoid the controversy over these expressions they will not be used. It is not necessary to discuss the equitable in personam claim for 'knowing receipt'. For an analysis of knowing receipt consistent with the approach here, see P Jaffey, 'The Nature of Knowing Receipt' (2001) 15 Trust Law International 151.
} 
because the claim takes the form of a claim of ownership of a specific asset, not a claim to pure value as such. ${ }^{20}$ The asset might be a tangible thing or a debt-right. For example, if money held on trust for the claimant-beneficiary by a trustee in a bank account is transferred by the bank at the direction of the trustee acting in breach of trust to a recipient R, by way of a transfer to R's bank account, then R is said to hold his contractual right to the account on trust for the claimant beneficiary, which is taken to mean that the claimant has an in rem claim to R's contractual right against his bank. As argued above, however, this is really a claim to wealth, i.e. the wealth represented for the time being as the balance on the account.

In principle, the claim arising from an invalid transfer of wealth should always be in rem, and it should not be necessary to identify a specific asset as being the subject matter of the claim. The claim should be in rem notwithstanding that it is a claim to wealth or pure value. As the following argument shows, there is no reason in logic or in principle against this position, although some may consider it a contradiction in terms. Say there is an invalid transfer of wealth from the claimant to the defendant, generating a claim against the defendant to reverse the transfer. The claim arises because the claimant suffers a loss of wealth that is the cause of a corresponding gain in wealth to the defendant through the invalid transfer. This can be expressed as a claim to 'surviving value', meaning the value in the defendant's estate due to the invalid transfer. This is value 'abstractly' or causally defined, which may but need not correspond to the value of a specific asset. Say that the invalid transfer to the defendant is followed by a transfer of surviving value to an indirect recipient, i.e., there is a transfer from the defendant to an indirect recipient that would not have occurred in the absence of the invalid transfer to the defendant. This should in principle give the claimant a claim against the indirect recipient for just the reason that he has a claim against the defendant direct recipient - the indirect recipient has received an invalid transfer from the claimant, the claimant's loss corresponding to a resulting gain to the indirect recipient. It follows that the claimant's right to surviving value, defined in terms of causation, subsists not only as against the recipient but also as against any third party. In other words, the claim to surviving value is in rem, notwithstanding that it is not a claim to a specific asset or tangible thing in the direct recipient's estate. Thus the surviving value should be treated as falling outside the

\footnotetext{
${ }^{20}$ As to the relation between 'separation of title' in equity and the availability of an in rem claim, and
} 
direct recipient's estate so far as third parties are concerned, and the claimant's right to surviving value should prevail over in personam claims against the defendant in insolvency. $^{21}$

One might object that the argument begs the question because it presumes that there is a claim against an indirect recipient of value, causally determined, whereas it is said that the law actually recognizes a claim against an indirect recipient only if the indirect recipient has received the claimant's property, or its traceable proceeds, and not merely by virtue of a transfer of surviving value causally defined. ${ }^{22}$ But the crucial issue here is what is meant by 'traceable proceeds'. As argued below, it is possible to make sense of this expression only on the basis that it identifies surviving value causally defined, and if this is the case this point does not undermine the suggested analysis. $^{23}$

This argument shows, contrary to what is generally assumed, that a claim to pure or abstract value need not necessarily be an in personam claim and that an in rem claim need not necessarily be in respect of a tangible thing or specific asset. It is not inconsistent with the nature of an in rem claim for it to subsist in respect of 'surviving value', even though surviving value is abstract value, defined in terms of causation. Reason and principle dictate that this should be recognized in the law. Furthermore, although the law ostensibly rejects this position, as just mentioned the law of tracing is inexplicable other than on the basis of an in rem claim to wealth or abstract value, as explained in the next section.

\section{Tracing}

Consider the case where the claimant has an in rem claim of ownership of a tangible thing in the defendant's estate, resulting from an invalid transfer. If the defendant exchanges the thing for some other thing - an 'exchange product' - under the law of tracing the claimant has an in rem claim to the exchange product. ${ }^{24}$ As it is sometimes

\footnotetext{
the related problem in recognizing an in rem claim at common law, see below text following n.83.

${ }^{21}$ The same argument is normally applied with respect to the ownership of tangible things, i.e., that the right of ownership is in rem and so binds indirect recipients and also third parties in an insolvency: see above at n.6. See also EL Sherwin, 'Constructive Trusts in Bankruptcy' [1989] University of Illinois Law Review 297.

${ }^{22}$ See e.g. A Burrows, The Law of Restitution (London, 1993), 48-9.

23 i.e. any such objection fails unless a rational alternative analysis of tracing can be offered.

${ }^{24}$ Re Hallett's Estate (1880) 13 Ch D 696.
} 
put, the in rem claim is transmitted to the exchange product. ${ }^{25}$ The same rule applies with respect to an asset in the form of a debt-right. Thus if the original thing received is sold for cash and the money placed in a bank account, the in rem right can be traced into the debt-right against the bank. Similarly if the original invalid transfer of wealth is paid directly into a bank account, and then transferred to a new bank account, the in rem right can be traced into the new bank account.

There is something paradoxical about the law of tracing as it is presently understood. On the one hand, the conventional understanding of tracing reflects the assumption that an in rem right can subsist only in respect of a specific asset, since it is conceived of as involving the transmission from one asset to another of a right to a specific asset. But tracing has to be explained on the basis that the claimant has a right to something other than merely the specific asset itself, because, if the right is purely and simply a right to the asset, it should (one would think) subsist only with respect to the asset and lapse (at least as against the defendant ${ }^{26}$ ) if the asset is lost from the defendant's estate. The persistence of an in rem right against the defendant notwithstanding the loss of the asset suggests that the claimant does not merely have a right in the asset itself. ${ }^{27}$

The problem can be resolved as follows. Consider first the case where there is an invalid transfer of wealth that is understood to give rise to an in rem claim in respect of a debt-right, as in the case mentioned above where trust money in an account is transferred to the recipient's account in breach of trust. Tracing can be explained on the basis that the claim is properly understood as a claim to causallydetermined 'surviving value' in the defendant's estate; and that this claim is in rem, notwithstanding that it is a claim to pure value, not a claim to a specific asset. As argued above, this is justified in principle, and there is nothing essentially illogical or conceptually impossible about it. Initially the surviving value is the value of the transfer, and so if the value received is put into an account, the surviving value is the value of the debt-right. If the money in the account is paid into a new account, or used to buy a tangible thing, the value of the exchange product will generally ${ }^{28}$ be the

\footnotetext{
${ }^{25}$ See generally LD Smith, The Law of Tracing (Oxford, 1997) for an analysis of tracing on these lines. Strictly speaking, on Smith's view, it must be that the in rem right is extinguished and a new in rem right in the substitute asset arises; the difference is not material for present purposes.

${ }^{26}$ The in rem right might persist as against an indirect recipient of the property.

${ }^{27}$ Smith, above $\mathrm{n} .25$ at 15 , does indeed emphasize that the subject matter of tracing is value; see also Foskett v McKeown [2000] 2 WLR 1299, 1323 per Lord Millett.

${ }^{28}$ See paragraph at $n .30$ below.
} 
surviving value after the transaction, i.e. the value now in the estate causally derived from the vitiated transfer. This is why it is justified to allow the claimant to make an in rem claim to the exchange product, or more precisely to the value of the exchange product. Surviving value is capable of surviving the loss of a specific asset, and it would be unfair to the claimant for the claim to be extinguished by the loss of a specific asset when there is surviving value still in the defendant's estate. The tracing rules are explicable as a means of determining the measure of causally-defined surviving value; it is a misapprehension to think that an in rem claim must necessarily subsist in a tangible thing or specific asset. ${ }^{29}$

In the case where the original transfer was of pure value, this is what the claimant seeks. It is of no concern to him what form the value now takes. But one might object that the argument cannot explain tracing in the case where the original transfer from the claimant was of a tangible thing. The argument above seems to imply that tracing in this case is explicable only on the basis that the claimant really has only a claim to the value of the thing, and no claim of ownership of the thing itself. Surely a claim of ownership of a tangible thing cannot be reduced simply to a claim to its value? But for the argument to prevail it is necessary only to say that if the claimant has a claim of ownership of a tangible thing he is entitled to treat the thing merely as a store of value or item of wealth and make a claim accordingly if it suits him to do so, i.e. he can treat the transfer just as if it were a transfer of pure value, its location in a specific asset or thing, as it were, being of no consequence. This is what he does when he makes a claim based on tracing, because here he claims the surviving value, which can survive the loss of the thing through an exchange.

This argument provides an explanation of tracing, but it also requires the tracing rules to be modified so that surviving value is always causally determined. As tracing is currently understood, under the exchange product rule the exchange product necessarily constitutes the traceable proceeds. This reflects what is sometimes called the 'transactional' analysis, by which it is the transactional link between the two specific assets that transmits the in rem right from one to the other. ${ }^{30}$ On the causation

\footnotetext{
${ }^{29}$ The tracing rules govern mixtures as well as substitutions, but mixtures have not been considered here.

${ }^{30}$ In the literature on tracing a distinction is drawn between causal and transactional theories of tracing: see e.g. DJ Hayton 'Equity's Identification Rules' in PBH Birks (ed), Laundering and Tracing (Oxford, 1995); S Evans, 'Rethinking Tracing and the Law of Restitution' (1999) 115 Law Quarterly Review 469. The literature does not appear to address the more fundamental issue of the nature of an in rem claim to pure value.
} 
approach suggested above, although the value of the exchange product will generally be the causally-defined surviving value, it will not be so where the exchange product would still have been acquired if there had been no invalid transfer. For example, if the defendant receives $£ 500$ and uses it to buy a car, the value of the car is the surviving value of the $£ 500$ (causally defined) only if the car would not have been bought if the $£ 500$ had not been received. ${ }^{31}$ On the approach proposed above, the exchange product rule should be understood not as a substantive rule of law but as an evidential convention or presumption of surviving value - i.e. of causation. ${ }^{32}$ Indeed it is often said that tracing performs an evidential function, ${ }^{33}$ but this is actually so only on the causation approach. On the transactional approach, the effect of the doctrine of tracing is to transmit ownership from one asset to another, and on this understanding it is not actually an evidential doctrine but part of the substantive law of ownership.

This causation approach also resolves a longstanding controversy concerning the doctrine of change of position. The claim arising from an invalid transfer is a claim to surviving value, defined in terms of causation. On this basis, where there is a loss to the defendant's estate that would not have occurred without the receipt, the surviving value is reduced by the measure of the loss. This principle is of course recognized at common law in the form of the doctrine of change of position. ${ }^{34}$ The doctrine protects the defendant from being unfairly prejudiced by the receipt, because it means that he cannot be left worse off than if he had not had the receipt. ${ }^{35}$ The doctrine applies where the defendant spends money only because he thinks he is richer by the amount of the receipt, or where there is loss or destruction of money or property in his estate that would not have occurred in the absence of the receipt.

\footnotetext{
${ }^{31}$ Similarly if the actual money or thing received is disposed of as a gift, under the current tracing rules there is no surviving value even if a gift of the same value would have been made anyway, so that in fact there remains surviving value under a causation test.

${ }^{32}$ Lord Templeman refers to what amounts to the exchange product rule as an evidential presumption in the context of change of position: see Lipkin Gorman v Karpnale [1991] 2 AC 548, 560. Presumably one might argue that for the sake of certainty and because of difficulties of proof it would be sensible to make the presumption irrebuttable. But this does not detract from the general argument concerning the nature of tracing.

${ }^{33}$ e.g. Foskett v McKeown [2000] 2 WLR 1299, 1323, per Lord Millett. Similarly, it is said that 'tracing is distinct from claiming' (ibid at 1324), which is so if tracing is indeed evidential but not if it is part of the substantive law of ownership of things as the transactional analysis implies.

${ }^{34}$ This assumes what is generally accepted, that change of position is to be defined causally, without a requirement of reliance by the defendant: see e.g. P. Birks, 'Change of Position: the Nature of the Defence and its Relationship to Other Restitutionary Defences' in MP McInnes (ed), Restitution: Developments in Unjust Enrichment (North Ryde, Sydney, 1996), 61.

${ }^{35}$ But where the defendant knows or ought to know that the transfer is vitiated, he can incur an in personam liability for knowing receipt: see above n.19.
} 
Sometimes the tracing rules achieve the same effect in equity. For example, if the value of an exchange product is less than that of the original product, there has been change of position and the defendant is protected in respect of it by the exchange product rule. ${ }^{36}$ But in equity, because the tracing rules as they stand are interpreted under a transactional approach, where this departs from a causation test there is no protection for change of position. For example, where a recipient spends money or makes a disposal of something that is not the tangible thing received, nor the substitute under the tracing rules for the value received, the tracing rules as they stand allow the claimant to recover the thing transferred or the substitute, or its full value, notwithstanding that the surviving value has diminished. Furthermore, the application in such a case of a separate doctrine of change of position to reduce the in rem claim of continuing ownership of a specific asset has generally been doubted, presumably because the concept of ownership seems to require that there be an indivisible claim to the asset. ${ }^{37}$ But the same principle of avoiding prejudice to the defendant resulting from the receipt is clearly applicable and so change of position should apply. ${ }^{38}$ The claimant should not be able to recover the asset itself or its full value if the measure of surviving value has declined to less than the value of the asset. The interpretation of tracing in terms of (causally-defined) surviving value rather than under the transactional approach will mean that this principle is incorporated into the law of tracing.

The interests of creditors of the defendant recipient are also prejudiced if a claim to a tangible thing is recognized as in rem when the value of the thing exceeds the surviving value in the defendant's estate. The claim should not leave creditors worse off than they would have been in the absence of the transfer - this would surely give the claimant unfair priority over creditors with respect to the pre-existing value of the defendant's estate. It follows that it is not justified in principle to have an in rem claim to a tangible thing except in so far as the value of the thing is the surviving value under a causation test. ${ }^{39}$

\footnotetext{
${ }^{36}$ As in Lord Templeman's example, above n.32. This is subject to the causation point above.

${ }^{37}$ For a discussion of the issue: see e.g. RC Nolan, 'Change of Position' in PBH Birks, (ed) above n.30, 135.

${ }^{38}$ As noted by P Birks, 'The Role of Fault in the Law of Unjust Enrichment' in G Jones and W Swadling (eds), In Search of Principle (Oxford, 1999), 271.

39 The claimant should be able to recover the thing if he makes up the shortfall in the estate. Furthermore, in principle, no claim should arise against an indirect recipient from the receipt of property derived from the claimant if the indirect recipient would have received a transfer of this value
} 
Thus it is justified, taking account of the interests of claimant, defendant and creditors, to treat a claim in respect of a specific asset or tangible thing arising from a transfer to the defendant as being a claim to the surviving value of the transfer, causally defined. As explained above, this does not mean that the claim is not in rem. Neither does it mean that there cannot be a claim of specific restitution in the case of a tangible thing, to recover the tangible thing itself. Such a claim should be permitted so long as the measure of surviving value has not fallen below the value of the thing. ${ }^{40}$ In the defendant's insolvency, because the claim to surviving value is in rem, and so will not diminish in competition with other claims, the claimant may still be able to get specific restitution of the thing. But he does not have an in rem claim because he is entitled to recover the thing from the defendant's estate, as the conventional position would have it; ${ }^{41}$ to the contrary, he is entitled to recover the thing because his claim to surviving value is in rem, and therefore does not diminish in the insolvency. ${ }^{42}$

Furthermore, although often the surviving value will be conveniently determined as the value of a specific asset in the defendant's estate, the claimant should in principle be able to trace into surviving value without having to identify any such specific asset. ${ }^{43}$ This idea of tracing into the estate as a whole has occasionally surfaced in the form of the 'swollen assets' doctrine of tracing, ${ }^{44}$ but has generally been rejected on the ground that an in rem claim must be a claim to a specific asset. ${ }^{45}$ Also the swollen assets doctrine has sometimes been thought to imply that the claimant is entitled to the full value of the transfer, irrespective of what has happened after receipt, rather than the surviving value of the receipt. ${ }^{46} \mathrm{An}$ in rem claim in the

anyway, but again the claimant should have right to recover the tangible thing if he gives the indirect recipient equivalent value.

${ }^{40}$ Again, the claimant should be able to recover the thing if he makes up the shortfall in the estate. The advantage of specific restitution as a remedy for the claim for surviving value is in avoiding the difficulty of determining the value of the tangible thing and in protecting the claimant in respect of its special value to him.

${ }^{41}$ See e.g. R Goode, 'Proprietary Restitutionary Claims' in WR Cornish et al (eds), Restitution: Past, Present and Future (Oxford, 1998), 65.

42 The analysis in the text might appear incapable of accounting for the case where the traceable value exceeds the value received; as to this, see at n.79 below.

${ }^{43}$ The common law rules on determining surviving value are equivalent to a 'swollen assets' test, since surviving value is causally defined. In principle, it would be relevant to locate the surviving value in a specific debt-right of the defendant in the case where that debtor is insolvent.

${ }^{44}$ Space Investments Ltd v Canadian Imperial Bank of Commerce (Bahamas) Ltd [1986] 1 WLR 1072, 1074, per Lord Templeman; see also DA Oesterle, 'Deficiencies of the Restitutionary Right to Trace Misappropriated Property in Equity and in UCCC s9-306’ (1983) 68 Cornell Law Review 172, 190.

${ }^{45}$ Smith, above n.25, 310; Re Goldcorp Exchange [1994] 2 All ER 806.

${ }^{46}$ This would be the effect of interpreting the swollen assets theory as giving the claimant a charge on the estate for the value transferred: see Smith, above n.25, 311. 
measure of value received would not be justified on the causation argument above and would be unfair to creditors of the defendant. ${ }^{47}$

The present law recognizes a distinction between traceable proceeds and surviving value, or, as the distinction has been put, between traceably and abstractly surviving value. ${ }^{48}$ Traceably surviving value consists of a tangible thing or specific asset (or a share of such) traced from the receipt by a process of substitution under the transactional approach, whereas abstractly-surviving value is the causally-determined surviving value, i.e. the surplus in the defendant's estate over the value it would have had without the receipt. Traceably surviving value is the subject of an in rem claim, the equitable proprietary claim, and developed as an equitable concept. Abstractly surviving value is the subject matter of an in personam claim, the claim for money had and received, subject to change of position, and developed as a common law concept. ${ }^{49}$ There is no doubt that this distinction is a part of the present law. But, on the argument above, traceably surviving value can be plausibly explained only as a proxy for or approximation to abstractly surviving value (but still, as argued above, as the subject of an in rem claim). On this approach, the two concepts should be integrated in due course. This can be achieved by way of the fusion of law and equity, which means in this context the integration of the equitable proprietary claim and the claim for money had and received. ${ }^{50}$

One might object that a satisfactory theory of tracing must account for the law of tracing as it stands, rather than as modified to accommodate the theory. But the theory proposed certainly supports a clearly recognizable concept of tracing. The issue is whether a more convincing alternative theory is available that supports the present law of tracing more precisely, i.e. in terms of tracing as the transmission from one specific asset to another of an in rem right that necessarily subsists in a specific asset. ${ }^{51}$ Various attempts to provide such a theory have indeed been made. In my view none of these is successful. ${ }^{52}$ One proposal is Birks's 'in rem power' theory. ${ }^{53}$

\footnotetext{
${ }^{47}$ The possibility of an in rem claim to abstract surviving value is also supported by the law of subrogation: see Jaffey, above n.8, 302-11.

${ }^{48}$ P Birks, above, n.34.

${ }^{49}$ Although of course the explicit recognition of change of position dates only from Lipkin Gorman $v$ Karpnale [1991] 2 AC 548.

${ }^{50}$ As proposed by Denning J in Nelson $v$ Larholt [1948] 1 KB 339. As to fusion, see also text following n.83. The causation analysis can also account for 'common law tracing' in relation to claims for money had and received or conversion, but these are not separately considered.

${ }^{51}$ See for example Smith, above n.25, 303ff.

${ }^{52}$ Some of these arguments are discussed in Jaffey, above n.8, 294-6.
} 
According to the power theory, where the claimant has an in rem claim to an asset that has been transferred to the defendant, he has a power to divest himself of the asset and appropriate to himself a substitute asset (identified by the tracing rules). It is difficult, first, to see how a claimant who invokes the law of tracing can be said to have exercised a power. It is in the nature of a power that it must be deliberately exercised, ${ }^{54}$ and it is difficult to see how the claimant in tracing cases can realistically be understood to have chosen to exercise a power to transmit his right of ownership to a substitute asset - in some cases the power would have to be exercised before the claimant has any knowledge of the claim. ${ }^{55}$ The facts of the cases themselves do not appear to disclose anything in the nature of an exercise of a power. Under this approach, in reality the transmission of the in rem right is simply deemed to have been effected by the exercise of a power, and so the power theory is no more than a restatement of the tracing rule by which the in rem right is understood to be transmitted from one asset to another.

More importantly, if tracing could realistically be understood to be based on the exercise of a power, an adequate theory of tracing would require some explanation of why the claimant has this power. The conventional understanding of an in rem claim assumed by the power theory is that it necessarily subsists in a specific asset. If this is so, it would seem to follow, as argued above, that the in rem claim should subsist only in the asset itself and be lost if the asset is lost. If the justification of the power is to preserve the position of the claimant in insolvency or as against an indirect recipient, notwithstanding the loss of the asset, by giving him a new and equivalent in rem claim, why is it that the claimant's position in this respect should be preserved? And if it is right to preserve the claimant's position, why should this not follow directly from the relevant events and circumstances, and instead be contingent on the exercise of a power by the claimant? The power theory (unlike the theory suggested here) offers no answer to these crucial questions. In reality the power is a fiction, which serves only to disguise the absence of any plausible explanation of

\footnotetext{
${ }^{53}$ Originally proposed in P Birks, 'Mixing and Tracing: Property and Restitution' (1992) 45 Current Legal Problems 69, 89; see the discussion in RB Grantham and CEF Rickett, Enrichment and Restitution in New Zealand (Oxford, 2000), 445ff. A version of the power theory seems to be alluded to by Lord Goff in Lipkin Gorman v Karpnale [1991] 2 AC 548, 573.

${ }^{54}$ This is not to say that the power-holder must be fully conversant with the details of the scope of the power or have a theoretical understanding of its nature.

${ }^{55}$ See Smith $\mathrm{n} .25$ above, 326 . Where there has been a series of exchanges, the power must be exercised retrospectively in relation to a substitute asset that has since been lost through a subsequent exchange.
} 
tracing in terms of the transmission of an in rem right from one specific asset to another.

\section{In rem claims and the apparent wealth argument}

The argument above implies that all invalid transfers of wealth or property should in principle generate an in rem claim, although of course this is not always recognized in the law. As compared to an in personam claim, the in rem claim can adversely affect third parties, i.e., indirect recipients and creditors. It is difficult to see why the existence of an in rem claim should be unfair to indirect recipients, provided that they are properly protected by change of position. As discussed above, there is the problem, for indirect recipients just as for direct recipients, that the tracing rules do not properly incorporate protection for change of position because as they stand they are not fully causation-based. ${ }^{56}$ But this risk of unfair prejudice to the recipient should be addressed through the change of position and tracing rules, not by denying that there is an in rem claim.

With respect to creditors of the recipient, there is an argument that suggests that an in rem claim can be unfair. ${ }^{57}$ This can be described as the 'apparent wealth argument'. Creditors inevitably rely on their judgment of the wealth of the debtor in making a decision to lend to him, or to give him credit in a transaction, or to refrain from calling in a debt. The receipt of an invalid transfer by the debtor will contribute to his apparent wealth, although because of the in rem liability for surviving value his actual wealth has not increased. Just as there is protection for a recipient who changes his position in reliance on an increase in his own apparent wealth resulting from the receipt of a transfer, by way of a reduction in his liability under the doctrine of change of position, so also, it seems, should there be protection for a creditor of the debtorrecipient as against the claimant to the extent of the creditor's reliance on the increase in the recipient's apparent wealth (where the recipient goes insolvent and cannot pay his debts). However, it is far from clear how this interest of the creditor should affect the claimant's position as against the insolvent recipient.

\footnotetext{
${ }^{56} \mathrm{~A}$ recipient, whether direct or indirect, is not protected by change of position insofar as he is taken to have acted wrongfully in disposing of surviving value when he knew or ought to have known of the vitiated transfer. Here the crucial issue determining the risk to the recipient is the level of his 'duty of inquiry': see further Jaffey, above n.8, 235, 329, 342, and above n.19.

${ }^{57}$ Sometimes the objection is simply that the recognition of an in rem claim means that the claimant is treated more favourably than a contract or tort creditor. The argument in the last section addresses this issue.
} 
Suppose that, in reliance on the apparent wealth of the recipient of an invalid transfer, a third party gives or refrains from withdrawing some measure of credit. The third party creditor could be given protection in respect of his reliance, analogous to that given to a direct recipient by change of position, by an appropriate reduction in the measure of surviving value in the recipient's estate, so that some part of the surviving value becomes available to the creditor. It seems that the appropriate reduction would be such as would increase the true value of the recipient's estate (i.e. its value excluding surviving value) to an amount such that the creditor (knowing this to be the position) would have acted in the way that he actually did with respect to giving or not withdrawing credit. ${ }^{58}$

In practice, applying an approach along these lines would be impossible. Even with respect to one creditor it would be very difficult to determine the effect of the receipt on the creditor's decision. But also different creditors would be aware of different facts and make different judgments at different times, and there would be no single measure of reduction of surviving value that would protect all of them in this way. One might argue that creditors should have the benefit of the doubt and therefore that in insolvency the surviving value should be reduced to nil and the claim eliminated or reduced to an in personam claim. ${ }^{59}$ But, to the contrary, it seems more reasonable generally to disregard the apparent wealth argument altogether, on the ground that, as a general rule, the increase in apparent wealth due to a particular invalid transfer is likely to contribute only marginally to the apparent wealth of the recipient, and to have only a marginal effect on any decision to grant or not to withdraw credit. ${ }^{60}$

Traditionally it has been only in equity that the claim to reverse a transfer is in rem, in the form of the equitable proprietary claim. At common law, the claim for

\footnotetext{
${ }^{58}$ It might also be argued that the recipient's own misunderstanding of his actual wealth may cause him to seek credit that he would otherwise not have sought. But it is doubtful whether this should affect creditor's position.

${ }^{59}$ There are traditional situations where the principle of apparent wealth has been influential, although not as against a restitutionary claim. For example, where security granted by a debtor is required to be registered, the rationale is the apparent wealth argument. Similarly, the rule that trust property should be kept segregated from the trustee's own property is surely based partly on the apparent wealth argument. Also at one time in the law of bailment where a bailed chattel was in the bankrupt's possession it was taken to be his and used for the benefit of his creditors under the old 'reputed wealth' doctrine. The apparent wealth argument would also be open to objection on the facts of a particular case on the ground that the creditor knew or ought to have known that there was surviving value in the recipient-debtor's estate or that in relation to certain types of transfer he ought to bear the risk irrespective of actual or constructive knowledge.
} 
money had and received has always been in personam. This means that claims to reverse a transfer in breach of trust or fiduciary duty have been in rem, whereas claims to reverse a mistaken payment, or a payment under a void contract, or a payment under duress, or an appropriation of money by a stranger, have generally all been in personam. But there is no apparent reason of principle why certain types of invalid transfer should generate an in rem claim and others an in personam claim, and in particular there is no apparent reason why it should be so significant that the claim arose from a transfer of wealth held under the control of a trustee or fiduciary, or that it was originally dealt with by the Chancery courts rather than the common law courts.

Not surprisingly, in some cases where traditionally only an in personam claim at common law has been available, there have been attempts to introduce the equitable proprietary claim. For example, in Chase Manhattan v Israel-British Bank, ${ }^{61}$ a case involving a mistaken payment, the judge contrived to characterize the claim as arising from a breach of fiduciary duty in order to hold that an in rem claim was available. But more recently, in Westdeutsche Landesbank Girozentrale $v$ Islington $B C,{ }^{62}$ the House of Lords rejected the argument that an in rem claim to reverse a payment made under a void contract could arise in equity; the only claim was the traditional in personam claim at common law. The decision against an in rem claim in Westdeutsche was based on an argument in the nature of the apparent wealth argument above. ${ }^{63}$ Lord Browne-Wilkinson was concerned at the risk to creditors arising from in rem claims because 'assets which apparently belong to one person in fact belong to another', which he described as the risk of 'off balance sheet' liabilities. ${ }^{64}$ But the court offered no basis for distinguishing, with respect to the apparent wealth argument, between claims that have traditionally arisen in equity and claims that have traditionally arisen at common law, or to explain why the risk to creditors is acceptable in the former category but not in the latter. ${ }^{65}$ The discussion

\footnotetext{
${ }^{60}$ It may be possible to specify particular circumstances in which the apparent wealth argument should be given some effect.

${ }^{61}$ [1981] Ch 105.

${ }^{6}$ [1996] AC 669.

${ }^{63}$ It seems that Lord Browne-Wilkinson was concerned about the position of third parties as indirect recipients as well as creditors; but, as argued above, indirect recipients can in principle be properly protected by change of position.

${ }^{64}$ At 705.

${ }^{65}$ Lord Browne-Wilkinson did accept that an in rem claim would be available in respect of stolen money, which would traditionally generate a common law claim ([1996] AC 669,716). This seems to
} 
above suggests that, on balance, all claims to reverse invalid transfers of wealth or property should be in rem, and that generally this is not unfair to creditors or indirect recipients.

\section{Property and unjust enrichment}

It was noted above that a distinction is usually drawn between two types of claim to reverse transfers of wealth or property. ${ }^{66}$ Broadly speaking, it seems that one is understood to be a claim based on the claimant's original ownership of property transferred, and the other on the principle of unjust enrichment. In other words, one is understood to be based on a primary right of ownership and the other on a primary right against unjust enrichment. It is said that the former arises from an invalid transfer, but the latter from a vitiated transfer, which may not be invalid. The former can be referred to as a proprietary claim and the latter as a restitutionary or unjust enrichment claim. ${ }^{67}$ Some commentators prefer to say that both claims are aptly described as restitutionary, since both serve to reverse a transfer, and that, to distinguish between the two, the latter claim should be described as an unjust enrichment claim; ${ }^{68}$ but in accordance with the more common usage the two claims will be referred to here as proprietary and restitutionary. Although there is a large literature on the issue, which assumes that there is a valid distinction between two claims along these lines, when it comes to identifying particular claims as examples of one or the other there seems to be very little consistency. ${ }^{69}$ This is not surprising, because, as is argued below, the supposed distinction is spurious, and there is in fact a

\footnotetext{
be because of the wrong committed by the defendant or an intermediary. But the commission of a wrong cannot justify an in rem claim, because the significance of an in rem claim is as against third parties, and there is no reason why third parties should be affected by the fact that the transfer was effected wrongfully.

${ }^{66}$ See at n.7.

${ }^{67}$ Some commentators are averse to using the word "proprietary" in this context: see the next paragraph. Instead one finds expressions like "property-protecting claim", "title-based claim", "vindicatio", "claim based on ownership", etc. But the distinction itself seems to be very widely expressed or assumed: see e.g. Smith, above n.25, 293; LD Smith, 'Unjust Enrichment, Property, and the Structure of Trusts' (2000) 116 Law Quarterly Review 412, 421; R Grantham and C Rickett, 'On the Subsidiarity of Unjust Enrichment' (2001) 117 Law Quarterly Review 273, 282-8; see also Foskett $v$ McKeown [2000] 2 WLR 1299, 1324-5, per Lord Millett, and Macmillan Inc v Bishopsgate Investment Trust [1996] 1 WLR 387.

${ }^{68} \mathrm{G}$ Virgo, The Principles of the Law of Restitution (Oxford, 1999), 11-16.

${ }^{69}$ For a recent discussion of this issue, see A Burrows, 'Proprietary Restitution: Unmasking Unjust Enrichment' (2001) 117 Law Quarterly Review 412. See also e.g. W Swadling, 'Property and Unjust Enrichment' in JW Harris (ed), Property Problems: From Genes to Pension Funds (Dordrecht, 1997), 130; P Birks, 'Property and Unjust Enrichment: Categorical Truths' [1997] New Zealand Law Review 623; LD Smith, above n.67; R Chambers, Resulting Trusts (Oxford, 1997).
} 
single category of claim to reverse an invalid (or vitiated) transfer of wealth or property, which encompasses these two supposedly distinct categories. The failure to appreciate this has given rise to unnecessary confusion and obscurity.

A preliminary point of terminology needs to be addressed. In this article the expression 'in rem' has been used until now, and this is often used interchangeably with 'proprietary'. 'Proprietary' is used here in contradistinction to 'restitutionary' or 'based on unjust enrichment' (as it might be used in contrast with 'contractual' or 'tortious'), to convey that the right in question arises from and by virtue of a right of ownership rather than from some independent principle like the principle against unjust enrichment (or, say, the principle that agreements should be observed). Thus it is used for the purposes of distinguishing between the two supposed claims above. By contrast 'in rem' is used in contradistinction to 'in personam' to refer to the character of a proprietary right or claim or of a right against unjust enrichment or of a restitutionary claim, as being good against the whole world.

The primary right of ownership and the primary right against unjust enrichment (assuming there to be two such distinct rights) are both in rem, because they both subsist as against any possible recipient. But it is generally thought that the proprietary claim and the restitutionary claim arising from these primary rights can each take the form of an in personam claim to value or of an in rem claim of ownership (which, on the conventional view, must be a claim to a tangible thing or specific asset, not to surviving value). A claim of ownership is of course generally described as proprietary, but for present purposes it is proprietary only if it arises from the primary right of ownership and not if it arises from the primary right against unjust enrichment. For example, the claim for money had and received at common law is sometimes said to be a proprietary claim (arising from pre-existing ownership of the money transferred) and sometimes said to be a restitutionary claim (based on unjust enrichment) ${ }^{70}$ but in both cases it is in personam not in rem. The 'equitable proprietary claim' to traceable proceeds, by contrast, is an in rem claim of ownership of the traceable proceeds of the transfer, but again it is sometimes said to be proprietary and sometimes restitutionary. ${ }^{71}$

\footnotetext{
${ }^{70}$ The general view seems to be that it can be one or the other depending on the circumstances. See e.g. the discussion in D Fox, 'The Transfer of Legal Title to Money' [1996] Restitution Law Review 60.

${ }^{71}$ See below at nn.75-77.
} 
It is worth noting that this multiplicity of types of claim is not a necessary feature of the approach adopted here, where there is a single category of claim to reverse an invalid (or vitiated) transfer, whether described as proprietary or restitutionary. This claim is a claim to surviving value, and is in principle always an in rem claim, notwithstanding that it is not necessarily a claim to a specific asset or tangible thing. If this position were adopted, it would not generally be necessary to distinguish between 'proprietary' and 'in rem' or between 'proprietary' and 'restitutionary' in relation to claims to reverse transfers. The complexity comes from the need to address the widely-held position that there are two types of primary right and that each can generate either an in rem claim or an in personam claim.

One might think that the distinction between proprietary and restitutionary claims corresponds to the distinction between claims arising from the ownership of tangible property and claims arising from the ownership of pure value, for example, money in the bank - i.e. between a primary right to pure value and a primary right to a tangible thing. Certainly it seems that the terminology of restitution developed largely in connection with money payments, whether in $\operatorname{cash}^{72}$ or by transfers from money held by way of a debt-right, ${ }^{73}$ and the proprietary terminology largely in connection with tangible property, like land and goods. ${ }^{74}$ Some would argue that it is inapt to refer to the right to wealth as proprietary where it is not a right to a tangible thing. But in any case, the distinction between proprietary and restitutionary claims is clearly not understood in the literature to correspond to this distinction between tangible property and pure value or abstract wealth. The literature clearly envisages that both proprietary and restitutionary claims can arise from the transfer of tangible property, and that both can arise from the transfer of pure value, for example money in an account. In any case, according to the analysis above, although specific restitution may be appropriate in the case of tangible property, but not pure value, the remedial regime is otherwise the same in the two cases - viz., the in rem claim to the surviving value of the transfer - and there is no reason to distinguish systematically between tangible property and pure value.

The obvious understanding of the distinction is that the proprietary claim protects the claimant against the loss of his property or wealth, whereas the

\footnotetext{
${ }^{72}$ Cash consists of a tangible thing as a token, not strictly 'pure value'.

73 i.e. the claim for money had and received at common law.

${ }^{74}$ e.g. chattels at common law and land held on trust and protected by the equitable proprietary claim.
} 
restitutionary claim removes an unjust enrichment from the defendant. But one would think that the reversal of a transfer always both protects the claimant's right to his wealth or property and also removes an unjust enrichment. These are two effects of the same claim - the opposite sides of the same coin - and do not imply that there are two categories of claim. The claim for the restoration of property or its value is justified because the defendant has received it and for him to retain it would be an unjust enrichment; and, conversely, the enrichment is unjustified vis-à-vis the claimant because the property or value in question was derived from the claimant by way of an invalid transfer (i.e. it is the surviving value of the claimant's property or wealth). In other words, there are not two primary rights, the right of ownership of the property or wealth and a distinct right against unjust enrichment, each of which can generate a claim to reverse a transfer of property or wealth, but just a single primary right from which the claim to the surviving value of the transfer arises. This primary right is the right of ownership, and its protection by the reversal of a transfer can also be said to prevent or reverse unjust enrichment.

The type of case which is often taken to illustrate the distinction between the proprietary and the restitutionary claims is as follows. ${ }^{75}$ Tangible property owned by the claimant is transferred to the defendant but the claimant retains ownership. The property is then lost, but there is surviving value in the defendant's estate. It might be said that once the property is lost there can be no claim based on protecting the claimant's property. The claim must be based instead on preventing the unjust enrichment of the defendant. But the claim to surviving value after the loss of the original property transferred remains a claim to recover the value of the original property, and so is surely a claim arising from the original primary right of ownership of property. This is so whether or not the argument above is correct in holding that the claim to abstractly surviving value is in rem. Where the original property is lost by way of an exchange and the claimant traces into the exchange product, some say that the claim in respect of the exchange product must be a restitutionary claim based on preventing the unjust enrichment that would otherwise result from the loss of the proprietary claim in respect of the original property, ${ }^{76}$ although others insist that the

\footnotetext{
${ }^{75}$ See e.g. LD Smith, above n.67; Burrows, above n.69.

${ }^{76}$ e.g. A Burrows, above n.69; P Birks, above n.69.
} 
claim to the substitute asset is proprietary not restitutionary. ${ }^{77}$ But again, whether or not the claim is really an in rem claim to abstractly surviving value, it can only be justified as a claim to recover value derived from the transfer of the original property, arising out of the claimant's ownership of the original property.

Conversely, it has been argued that for so long as the claimant retains ownership of property in the defendant's estate there can be no claim based on unjust enrichment, because if the claimant retains ownership the defendant has received no actual benefit (mere possession without ownership being no benefit at all), and so there can be no claim based on unjust enrichment. ${ }^{78}$ But this proves too much, because, although it might seem reasonable to say that the effect of the claimant's continuing ownership is to pre-empt any unjust enrichment of the defendant, the same can be said with respect to any claim to surviving value (whether or not the claim is in rem). The accrual of the claimant's claim to surviving value pre-empts what would otherwise be the unjust enrichment of the defendant. ${ }^{79}$

The distinction is sometimes expressed in terms of title (signifying ownership). It is said that there is a proprietary claim if the transfer is invalid, so that it is ineffective to pass the claimant's title to the property or wealth, which survives the transfer of the property to the defendant (even if the title is subsequently lost); but if the transfer is valid, so that the claimant's title is lost in the transfer, there can only be a restitutionary claim, based not on the claimant's title but on the fact that the transfer was vitiated and the defendant therefore unjustly enriched. ${ }^{80}$ Thus retention of title, or invalidity of the transfer, is contrasted with the presence of a vitiating factor as the basis for the claim. But where title is retained in the face of a putative transfer, there must be some factor rendering the transfer of title invalid - i.e. a vitiating factor. The usual vitiating factor in cases described as being cases of retention of title is lack of authority, where money or property is simply taken by a stranger without

\footnotetext{
${ }^{77}$ e.g. Virgo, above n.68, 595; W Swadling, 'A Claim in Restitution?' [1996] Lloyds Maritime and Commercial Law Quarterly 63.

${ }_{78}$ e.g. Swadling, ibid; Foskett v McKeown [2000] 2 WLR 1299, 1324-5 per Lord Millett.

${ }^{79}$ Sometimes a claim is in a measure that exceeds the surviving value, as where the defendant has made money using the value received, for example by using it in his business. Thus it appears that the claim must be based on unjust enrichment. But in such a case the claim to surviving value should be distinguished from the further claim for payment for the unauthorized use of the claimant's wealth, or for disgorgement of profits obtained through a breach of duty to the claimant: see Jaffey, n.8 above, at 311.

${ }^{80}$ e.g. Smith, above n.67.
} 
permission or transferred by an agent without authority. ${ }^{81}$ In such cases the vitiating factor is too obvious to be mentioned. This supposed difference between proprietary and restitutionary claims is purely terminological. One can always express a claim based on an invalid transfer or retention of title as a claim arising from a vitiating factor, and vice versa. As assumed above, the vitiation of the act of transfer (meaning that it is not a valid exercise of the power of disposition) means that the transfer is invalid.

One might object that this argument is contradicted by the case law, according to which where there is a valid transfer of title, and so no possibility of a proprietary claim, the transfer can nevertheless be vitiated and so generate a restitutionary claim. For example, it is sometimes said that whereas a fundamental mistake is necessary to stop title passing, any causative mistake can vitiate a transfer, so that if there is a causative but non-fundamental mistake there can be a restitutionary but not a proprietary claim. ${ }^{82}$ But this merely begs the real question at issue, which is whether there is a basis in principle for the distinction. If the claimant has validly disposed of property or wealth in favour of the defendant, how can the defendant be unjustly enriched at the claimant's expense by the receipt of it? In relation to tangible property, the assumption may be that in some sense the claimant can have a right to the value of his property that is to be distinguished from his right of ownership of the property itself, and that somehow the claimant can validly transfer the right to the property itself, whilst retaining the right to its value. But it is difficult to see how these could be distinguished, or, for that matter, how different criteria could apply to determine when they had been validly transferred. ${ }^{83}$

Some of the difficulties concerning the usage of 'title' would be obviated by the recognition of the fact that there are really two distinct forms of 'title'. This is of course recognized in equity, in the form of legal and equitable title. But the functional distinction between the two forms of title is obscured by the jurisdictional origins of the expressions. It is sometimes thought that in some sense the two forms of title represent rival claims of ownership derived from a conflict between law and equity. But, in terms of function, legal title represents a power to control and to dispose of

\footnotetext{
${ }^{81}$ See above at n.8. Thus it is argued that there is no vitiating factor of 'ignorance' (i.e. lack of authority) because in any case where it might be thought to apply the claim is proprietary not restitutionary: see Swadling, above n.77.

${ }^{82}$ See the discussion in Fox , above n.70.
} 
property or wealth, whereas equitable title represents a right to the value or benefit of property or wealth (in circumstances where someone else has control of it). ${ }^{84}$ These are two (undifferentiated) aspects of the absolute ownership recognized at common law. Legal title must by its nature relate to a tangible thing or specific asset (including a debt-right, where it signifies the power to deal with the debtor, e.g. the bank); but equitable title can, in accordance with the argument above, signify abstract or causally defined value, including the surviving value of a vitiated transfer. It might be helpful to designate the two forms of title as 'dispositive title' and 'beneficial title' rather than legal and equitable title, ${ }^{85}$ in order to emphasize their functional significance rather than their historical origins, but the traditional terminology will be used here.

Where the claim arising from an invalid transfer is dealt with in equity - i.e., typically where it is a transfer in breach of trust or fiduciary duty - the claim takes the form of a separation of title: this is the equitable proprietary claim. The claimant retains the equitable title ${ }^{86}$ - the claim to surviving value - but the recipient acquires the legal title - the power of disposition in favour of bona fide purchasers, notwithstanding that the transfer is invalid. The effect of recognizing the recipient as having legal title is to protect bona fide purchasers from the recipient of the property transferred. In the case where there is an invalid transfer of wealth into the defendant's bank account, the legal title of the defendant recipient signifies his authority as the bank's creditor to deal with the bank and others with respect to the wealth in question. Thus 'separation of title', as a response to an invalid transfer, is a device for allowing the claim to reverse the transfer to be expressed in terms of an assertion of title - i.e., recognizing an in rem claim - whilst also protecting the interests of third parties.

By contrast at common law there is one title, which signifies both the right to value and the power of disposition, i.e. absolute ownership. This gives rise to the following problem in relation to invalid transfers. If the claim against the direct recipient takes the form of an assertion of title, as in the case of chattels, ${ }^{87}$ it must

\footnotetext{
${ }^{83}$ The spuriousness of the distinction seems to be particularly clear where the primary right is to wealth, as in the case where there is a transfer of money from an account.

${ }^{84}$ The argument does not apply to 'equitable interests' in general, if these are taken to include interests other than interests under a trust e.g. equitable leases, mortgages etc.

85 'Beneficial title' is of course in general use.

${ }^{86}$ One might say that the claimant 'acquires' rather than 'retains' equitable title, at least in the case where he started with absolute ownership, but nothing of importance turns on this for present purposes.

${ }^{87}$ The claim is described as a claim for conversion or interference with goods, but is also understood as a proprietary claim based on retention of title to the goods.
} 
follow that the direct recipient acquires no title, and this is taken to preclude any protection for third party purchasers. The retention of title does, however, allow for the possibility of an in rem claim against the direct recipient. ${ }^{88}$ The third party is protected only if title has passed to the direct recipient, but this appears to mean that there can be no claim against the direct recipient in the form of an assertion of title, i.e. no in rem claim. Where there is an invalid payment of money into the defendant's account, it would seem that title to the account must be with the defendant as the creditor of the bank, leaving no room for a claim in the form of the assertion of title to the account. ${ }^{89}$ The same is the case where there is an invalid payment of money as notes or coins, where there is good reason to treat the recipient as having title so far as dealings with third parties are concerned, in order to maintain the efficacy of the notes or coins as currency. In these cases, there is an obvious temptation to say that, although the transfer was valid to pass title, it was vitiated and there is a restitutionary claim against the direct recipient, although it would seem (because the claim is not based on the assertion of title) that the claim must be in personam. This is the usual understanding of claims arising from invalid payments of money at common law. ${ }^{90}$ The problem is the impossibility at common law of distinguishing between a dispositive title, signifying the power of disposition to third parties, including the power to deal as creditor in respect of a bank account or other debt-right, and a beneficial title, signifying the right to surviving value, and so of reconciling the existence of an in rem claim with any degree of protection for third parties. ${ }^{91}$

Once the possibility of separation of title is accepted, one can say that the beneficial title signifies the restitutionary claimant's right to surviving value, and that in order to protect third parties the dispositive title always goes with possession and control of property, or, in the case where wealth is transferred into the defendant's

\footnotetext{
${ }^{88}$ It seems that an in rem claim giving priority in insolvency may be available in respect of a chattel at common law, although it may be that this is only the effect of equity: the issue arises in connection with Taylor v Plumer (1815) 33 M \& S 562, as considered in LD Smith, 'Tracing in Taylor v Plumer: Equity in the Court of King's Bench' [1995] Lloyds Maritime and Commercial Law Quarterly 240.

${ }^{89}$ In Trustee of the Property of FC Jones and Sons $v$ Jones [1996] 3 WLR 703, money was transferred without authority into an account of the defendant's. It seems to have been held that the claimant retained legal title to the money in the account, but this is difficult to reconcile with the fact that the contractual relationship of the bank was with the defendant and the account in the defendant's name.

${ }^{90}$ Similarly, where the claimant makes a transfer under an invalid contract, by holding the contract to be voidable rather than void the court allows itself to find that the direct recipient (the other contractor) has a title and can give good title, but that the claimant has a restitutionary claim (in the form of a claim to rescind the contract and reverse a transfer under it).
} 
account, with the defendant's status as contractual creditor. There will be no temptation to say that title has passed but that there is nevertheless a claim based on a vitiated transfer. The fusion of law and equity (which entails the recognition of the functional as opposed to an historical or jurisdictional distinction between legal and equitable title ${ }^{92}$ ) will eliminate this source of confusion concerning title and allow for a rational balancing of interests between the restitutionary claimant and third parties through the concept of separation of title, ${ }^{93}$ in all cases and not just in those traditionally dealt with in equity, just as it will advance the law concerning tracing and the availability of the in rem claim, as argued above. ${ }^{94}$

\section{The theory of unjust enrichment}

There is another reason why the distinction between proprietary and the restitutionary claims is generally accepted. The theory of unjust enrichment is now said to have been recognized in English law. ${ }^{95}$ The theory can be summarized as follows. ${ }^{96}$ There are various circumstances in which the fact that the defendant has received a benefit is an element of the cause of action. Historically, claims in such circumstances have taken a variety of different forms. The theory holds that there is a single principle the principle against unjust enrichment - which provides the underlying justification for these various claims. The recognition of the principle allows what has historically appeared to be a haphazard and incoherent miscellany of claims to be properly understood as examples of the application of the same principle. This will allow for a more coherent formulation and development of these claims. This field of law has commonly been described as the law of restitution, or the law of restitution for unjust enrichment, 'restitution' being taken to refer to the appropriate remedial response to

\footnotetext{
${ }^{91}$ But it should be noted that the common law does overcome this problem in relation to money by the recognition of a bona fide purchase defence that does not depend on a derivative title but on a new title: see as to non-derivative title, Fox, above n.70.

${ }^{92}$ See further Jaffey, above n. 8, Appendix 2.

${ }^{93}$ In this exercise the crucial issue is the level of the duty of inquiry of the recipient: see further Jaffey above n.19.

${ }^{94}$ See above at n.50.

${ }^{95}$ It is said to have been recognized by Lipkin Gorman v Karpnale [1991] 3 WLR 10; see e.g. P Birks, 'The English Recognition of Unjust Enrichment' [1991] Lloyds Maritime and Commercial Law Quarterly 330, A Burrows, Understanding the Law of Obligations (Oxford, 1998), 99.

${ }^{96}$ See e.g. Burrows, ibid, Chapter 5.
} 
unjust enrichment, viz., transferring the defendant's unjust enrichment to the claimant. $^{97}$

One type of case taken to fall within the field of restitution for unjust enrichment is the non-contractual claim for payment for services. Generally a claim for payment for services is made in contract, and generally in the absence of a contract a claim for payment for services will not arise. But there are exceptional circumstances where a claim for payment may arise in the absence of a contract - for example where the services are provided by mistake or in an emergency. This is said to be a restitutionary claim based on the unjust enrichment of the defendant resulting from the provision of the services. Also, it is generally thought that a restitutionary claim based on unjust enrichment can in certain circumstances arise in respect of services conferred under a valid contract. Another claim supposed to be based on unjust enrichment is the claim for profit made by the defendant through a wrongful act against the claimant. The claim serves to prevent the defendant from profiting from his wrongdoing. ${ }^{98}$ This category of claim has been described as 'restitution for wrongs ${ }^{99}$ or 'unjust enrichment for wrongs' or 'disgorgement'. ${ }^{100}$ But the most important and common example of a claim based on unjust enrichment is understood to be the restitutionary claim to reverse a vitiated transfer of wealth or property discussed above (which has traditionally taken the form of money had and received or the equitable proprietary claim). This claim is taken to lie at the heart of the law of restitution governed by the principle of unjust enrichment.

As discussed above, this claim to reverse a transfer based on unjust enrichment is understood to be distinguishable from the proprietary claim to reverse a transfer based on the claimant's pre-existing ownership. The argument above that the distinction is spurious presents a difficulty for proponents of the theory of unjust enrichment. If there is no such distinction, one possibility (for a proponent of the theory) might be to argue that all claims to reverse invalid transfers of wealth or

\footnotetext{
${ }^{97}$ This summary reflects the position adopted in most restitution textbooks. There is some controversy amongst supporters of a theory of unjust enrichment over the true relationship between restitution and unjust enrichment. It is not necessary to pursue this issue, which is partly a matter of usage.

98 A standard case of disgorgement is where the defendant has made a profit through a breach of fiduciary duty to the claimant, e.g. by taking a bribe, as in A-G for Hong-Kong v Reid [1994] 1 AC 324. ${ }^{99}$ This expression is due to Birks, above n.8.

${ }^{100}$ LD Smith, 'The Province of the Law of Restitution' (1992) 71 Canadian Bar Review 672; P Jaffey, 'Restitutionary Damages and Disgorgement' [1995] Restitution Law Review 30. 'Restitution for wrongs' has been thought to form a separate category of response, although apparently governed by the same principle of unjust enrichment.
} 
property fall under the principle of unjust enrichment. This position has not generally been adopted: ${ }^{101}$ pre-existing ownership has been accepted as a distinct basis for such a claim. It would be implausible to assimilate claims based on ownership with claims for payment for services and claims for disgorgement which clearly do not arise from pre-existing ownership. ${ }^{102}$ The unpalatable alternative is to accept that what has always been thought of as the major part of the law of restitution for unjust enrichment - claims to reverse vitiated transfers - must be excluded from it. Thus one can see the appeal of the distinction, however difficult it may be to pin down. ${ }^{103}$

In fact, the theory of unjust enrichment (as expressed above) is misconceived, and it has imposed a false division on the law of invalid transfers, at great cost in terms of confusion and misdirected argument. ${ }^{104}$ This conclusion is consistent with the fact that, although claims for the reversal of invalid transfers historically came in various forms, until the development in recent years of the theory of unjust enrichment the law seems to have been untroubled by the possibility of a systematic division between two categories of invalid transfer based on different principles and protecting different interests. Furthermore, it should be added, none of the recent cases that appear to recognize the principle of unjust enrichment addresses either the question how to distinguish between two categories of claim to reverse invalid transfers, or the question whether claims to reverse invalid transfers of wealth or property are really based on the same underlying principle as other claims arising from the receipt of a benefit, like non-contractual claims for payment for services rendered, claims based on benefit received under a valid contract, and claims for

\footnotetext{
${ }^{101}$ Save by Burrows, who at one time treated 'retention of title' as an 'unjust factor': see Burrows, above n.22, Ch 13 .

${ }^{102}$ The provision of services is not a transfer of property or wealth, or indeed a transfer at all in any normal sense, and the claim cannot be expressed as a claim to wealth or surviving value derived from the transfer. A disgorgement claim is not a claim to the surviving value of a transfer of wealth or property from the claimant, and the benefit may not be derived from the claimant at all.

${ }^{103}$ It has been argued by supporters of the theory of unjust enrichment that the restitutionary claim to reverse a vitiated transfer based on unjust enrichment cannot be reduced to the proprietary claim - i.e. it must be distinct from it - because some claims based on unjust enrichment (e.g., claims for payment for services) clearly cannot be proprietary, and so a claim based on unjust enrichment must be distinct from a claim based on ownership of property or wealth: see e.g. Smith, above n.67, 419; and this is implicit in Burrows above, n.69, 415. But this simply begs the question whether claims for payment for services and claims for disgorgement are indeed governed by the same principle as (any type of) claim to reverse a vitiated transfer of wealth or property.

${ }^{104}$ It is surely also clear that claims for payment for services are quite distinct from claims for disgorgement, and so the field of restitution for unjust enrichment as it has been widely understood actually mistakenly assimilates quite distinct types of case. Claims arising on the termination of a valid contract that are dependent on receipt by the defendant are best understood as contractual claims. This argument is outlined in Jaffey, above n.8, Chapter 1.
} 
disgorgement. ${ }^{105}$ The rejection of the theory of unjust enrichment as described above does not of course imply that there are not claims for which the receipt of a benefit is relevant, or that in this loose sense there are unjust enrichment claims. Neither of course does it deny that there are restitutionary claims. But 'restitution' is best used to refer only to claims to reverse transfers, not claims for payment or disgorgement claims which do not serve to reverse transfers. A restitutionary claim to reverse an invalid transfer is also a proprietary claim, in the sense that it arises from a right of ownership of wealth or property. ${ }^{106}$ One can also say that such a claim serves to prevent unjust enrichment, but this is just to emphasize an aspect of the proprietary claim: the claimant's continuing right to his own wealth or the surviving value of his property entails that the defendant should not have it.

\section{Conclusion}

There can be an in rem right to wealth, including pure value, just as there an be an in rem right to tangible property. An invalid transfer of wealth, whether of tangible property or pure value, generates a claim to the surviving value of the transfer, defined as the surplus in the defendant's estate over the value the estate would have had in the absence of the receipt. The claim to surviving value is in principle an in rem claim and should be recognized as such, notwithstanding that it is not necessarily a claim to a tangible thing or specific asset. 'Traceable proceeds' (whether derived from a transfer of pure value or of a tangible thing) should be understood as a proxy for or approximation to surviving value causally defined. These propositions provide a rational foundation for the doctrine of tracing, and they offer a solution to the controversy over the availability of in rem restitutionary claims.

There is no valid distinction to be drawn in relation to the reversal of transfers between a claim based on the pre-existing ownership of wealth or property and a claim based on the principle of unjust enrichment; these are two perspectives on the same claim. Thus there is no basis for distinguishing between an invalid transfer of wealth or property, which does not pass title, and a transfer that is valid insofar as the passage of title is concerned but vitiated for the purposes of generating a claim based

\footnotetext{
105 This is true of e.g. Lipkin Gorman v Karpnale [1991] 3 WLR 10, Banque Financière de la Cité v Parc (Battersea) Ltd [1998] 2 WLR 475, Portman Building Society v Hamlyn Taylor Neck [1998] 4 All ER 202.

${ }^{106}$ One might also defend the use of "restitution" to refer to a claim to reverse a transfer arising in contract, say, and not from a vitiating factor, although this may depart from current usage.
} 
on the principle of unjust enrichment. The supposed distinction is an unfortunate artefact of the theory of unjust enrichment, which, whilst necessarily conceding that ownership provides an independent basis for a claim to reverse a vitiated transfer, has also wrongly brought together some claims to reverse vitiated transfers with noncontractual claims for payment for services and claims for disgorgement under the rubric of unjust enrichment. This has been a source of great confusion in the analysis of claims arising from invalid transfers of wealth or property. 